\title{
Effect of Economic Factors on Tax Compliance in Kenya: A Survey of Limited
}

\section{Liability Companies within Eldoret Municipality}

\author{
${ }^{\mathrm{a}}$ Kosgei David KIpkoech, ${ }^{\mathrm{b}}$ Tenai Joel \\ ${ }^{\mathrm{a}}$ Department of Management Science, School of Business and Economics, Moi University, Eldoret, Kenya \\ ${ }^{\mathrm{b}}$ Department of Accounting and Finance, School of Business and Economics, Moi University, Eldoret, Kenya
}

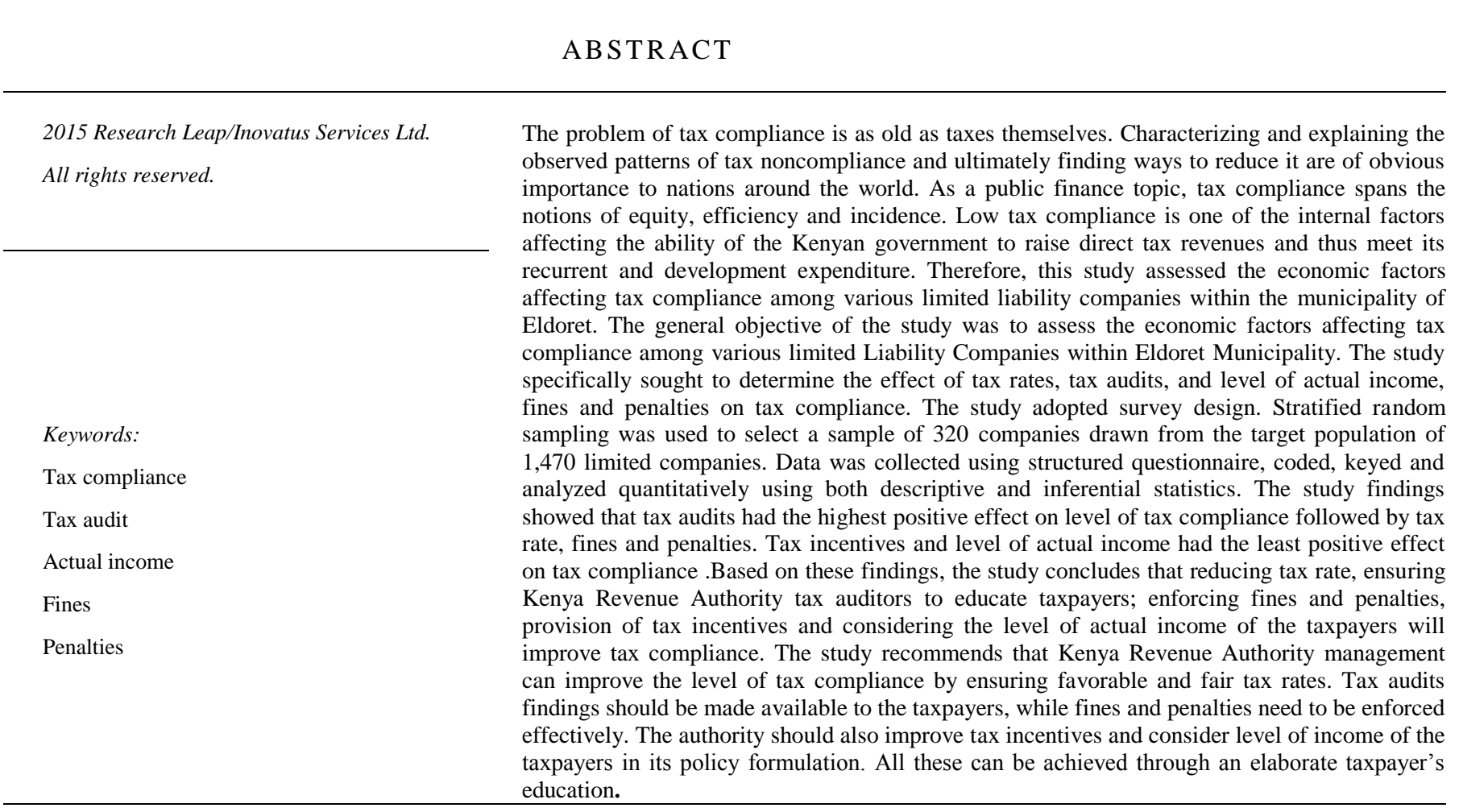

\section{Introduction}

The $21^{\text {st }}$ century is more dominated by knowledge economy, many firms are shifting from using physical capital and embrace intellectual capital, as more and more firms are trying to find better ways to use their resources efficiently in order to sustain in the dynamic changing business environment, hence there is a drastic move by many firms from production era to knowledge era and from production labor to knowledge worker (Lipunga, 2014). It is no secret that the organization that continues to invest in new skill and technology will continue to be successful. Thus, intangible assets, especially, knowledge are gaining prominence than ever before as a matter of survival and of achieving competitive advantage for the firm to compete strategically (Latif et al., 2012). In today's fast moving economy with the rapid growth of knowledge and technology innovation, the growth of organization has changed to cope with the changing environment. With amounting competitions in the global economy, intellectual capital has become the main ingredient and vital for the organization to sustain the competitive world in which they operate and create more values. Thus, it can be put as an established fact by (Bontis, 2001) that intellectual capital has become the critical driver for sustainability.

Although the grounded framework of intellectual capital have been in place and intellectual capital is being studied in many countries as a way for firms to gain competitive advantage over rivals, there is still a gap in understanding intellectual capital as a critical asset worthy to invest and use. Therefore, there is a need to measure intellectual capital of the firm and its impact on financial performance in order to create more awareness. Furthermore, many studies have focused the research of intellectual capital in the developed world, there have been very few studies that have used emerging developing world country, especially, Sub-Saharan Africa as a case for evaluating the implications of intellectual capital for specific industries like banks (Kamath, 2007). This has created a gap that needs to be 
addressed because, with rapidly changing environment filled with innovation, information and technology, firms [both in developed and developing economies] are increasingly threatened with global competition (Muhammad and Ismail, 2009), which makes intellectual capital more important to achieve sustainability and competitive advantages. Thus, there is still a need to promote more studies in developing countries.

This study uses the bank sector to find the relationship between intellectual capital and financial performance of banks. Since the bank is one of the highest knowledge-intensive sector, research on the case of banks provides a rich environment for the research. There is also availability of the reliable data from the audited annual reports of banks. The study uses $\mathrm{VAIC}^{\mathrm{TM}}$ model to analyze an impact of intellectual capital on financial performance of Tanzanian banks.

\section{Literature review}

\subsection{The Concept of Tax Compliance}

Tax compliance is a major problem for many tax authorities and it is not easy task to persuade taxpayers to comply with tax requirements even though 'tax laws are not always precise' (James and Alley 2004). The definition of tax compliance in its most simple form is usually cast in terms of the degree to which taxpayers comply with the tax law (James 1999). However, like many such concepts, the meaning of compliance can be seen as a continuum of definitions. One suggestion is that the degree of non-compliance may be measured in terms of the 'tax gap'. Tax gap represents the difference between the actual revenue collected and the amount that would be collected.

\subsection{Tax Non-compliance}

Tax non-compliance is defined as failure to comply with tax laws and/or report incorrect income, the act of claiming incorrect deductions, relief and rebates and/or paying the incorrect amount of tax beyond the stipulated time frame (Mohd et al, .2011). Noncompliance is also perceived as the failure of a taxpayer to report (correctly) the actual income, claim deductions and rebates and remit the actual amount of tax payable to the tax authority on time (Kirchler, 2007). Taxpayers vary in terms of the opportunities available to them to overstating expenses and understating incomes (Chau and Leung 2009). Greater tax noncompliance opportunity is generally resulted from selfemployment and income sources not subject to withholding taxes.

\subsection{Tax Compliance Models}

In explaining taxpayer's compliance behavior, that is, the reasons why taxpayers comply or do not comply, there are two broad approaches which researchers have used to explain evasion behavior, namely, Fiscal Psychology Models and Economic Deterrence Models. Economic based theories emphasizes incentives whereas psychology-based theories emphasizes attitude (Trivedi \&Shehata, 2005).

Economic theories of tax compliance are also referred as deterrence theory. According to Trivedi and Shehata (2005), economic theories suggest that taxpayers "play the audit lottery," for instance, they make calculations of the economic consequences of different compliant alternative, such as whether or not to evade tax; the probability of detection and consequences thereof, and choose the alternative which maximizes their expectation after tax return/profit (possibly after adjustment for the desired level of risk). The theories suggest that taxpayers maximize utility hence; economic theories emphasize increased audits and penalties as a solution to compliance problems. Economic based studies suggest that taxpayers' behavior is influenced by economic motives such as profit maximization and probability of detection (Trivedi \& Shehata, 2005), underreporting (Erard \& Ho, 2002; Cobham, 2005), business income taxpayers operating in informal economy (Etchberry, 1992) among many factors. Psychology theories of tax compliance assume that psychological factors including moral and ethical concerns are also important to taxpayers and taxpayers may comply even where the risk of audit is low. Psychology theories de-emphasize audits and penalties and instead focus on changing individual attitudes towards tax system. Trivedi and Shehata (2005) concluded that some taxpayers' behavior may follow economic theories while others may follow the psychological theories and a mixture of the two is also possible.

\subsection{Tax Rates and compliance level}

This subsection discusses how tax rates influence taxpayer's decision to comply with tax laws. Clotfelter (1983) claimed that 'reducing tax rates is not the only policy that has the potential to discourage tax evasion' but the tax rate is also an important factor in determining tax compliance behavior although the exact impact is still unclear and debatable (Kirchler et al, 2007).

Tax rates have mixed impact on tax compliance. Allingham and Sandom (1972) attempted to find a relationship between actual income, tax rates, penalty and tax evasion using statistical modeling. They concluded that the taxpayers may choose either to fully report income or report less, regardless of tax rates. Tax rates appeared to be insignificant in determining tax evasion.

In contrast with Allingham and Sandom (1972), various studies found that increasing tax rates encouraged non-compliant behavior. Alm et al., (1992); Friedland et al. (1978) claimed that increasing tax rates leads to tax evasion. Since the impact of tax rates have mixed impact on tax compliance was debatable, Kirchler et al. (2008) suggested that the degree of trust between taxpayers and the government has a major role in ascertaining the impact of tax rates on compliance.

When trust is low, a high tax rate could be perceived as an unfair treatment of taxpayers and when trust is high, the same level of tax rate could be interpreted as contribution to community (Kirchler et al., 2008).In Kenya, Corporation Income Tax is levied on corporate bodies. Resident Companies are taxable at a rate of $30 \%$ while non-resident Companies are taxable at the rate of $37.5 \%$ on taxable income (IT Act Cap 470).

VAT is charged at $16 \%$ which is a general rate and at $0 \%$ for all categories of goods and services that are zero rated (VAT Act cap 476). In summary evidence suggests tax rates have mixed impact on tax compliance i.e. decreasing tax rates does not necessarily always increase compliance (Kirchler et al., 2008) and increasing tax rate will not necessarily always decrease compliance behavior (Allingham and sandom,1972) the study hypothesize that Tax compliance is not affected by tax rates.

\section{Hol: Tax rates have no significant effect on tax compliance.}

\subsection{Tax Audits and compliance level}

Tax Audit is one of the most effective policies to protect the behavior of tax evasion (Hyun 2005). The level of tax audit can be determined by two elements; how many taxpayers are selected for audit and how much intensive is the audit.

The first element is easily measured by the number of audited taxpayers divided by the number of taxpayers. However the 
second element is so difficult to measure due to no published information about the process of tax audit. Tax audits need the administration cost. With the constraint of the fixed administration cost, an increase in the level of tax audit is required to decrease the level of other administration functions like taxpayer service, tax collection (Hyun 2005).

Audit rates and the thoroughness of the audits could encourage taxpayers to be more prudent in completing their tax returns, report all income and claim the correct deductions to ascertain their tax liability. In contrast, taxpayers who have never been audited might be tempted to under report their actual income and claim false deductions (Mohd et al., (2011). Mohd (2011) claimed that audits have a positive impact on tax evasion. His findings suggest that in Self-Assessment Systems, Tax Audits can play an important role and their central role is to increase voluntary compliance.

Friedland et al., (1978) found that a higher (random) audit rate leads to more compliance. However Alm et al., (1992) find that this impact appears to be small and nonlinear, so that the deterrent effect of a higher audit rate eventually disappears. They also find that many subjects appear to substantially overweight the probability of an audit, so that there is far more compliance than is predicted by expected theory. Previous studies have evidenced that tax audits play an important role in increasing voluntary compliance. Audits rates and the thoroughness of the audits could potentially encourage taxpayers to be more prudent in completing their tax returns. The study hypothesize that Tax Audits does not influence Tax compliance.

\subsection{Level of Actual Income}

Predictions of the standard economic model in regards to income effects on tax compliance are ambiguous. Though wealthier citizens are more likely to evade taxes since the level of absolute risk aversion decreases with income, it is not clear if severity of evasion is an increasing or decreasing function of income (Kirchler et al., 2007).Once taxpayers have decided to evade taxes, the degree of underreporting depends on the relative risk aversion. The relation of income and relative risk aversion is not unique and consequently Allingham and Sandom (1972) conclude 'that when actual income varies, the fraction of income declared increases, stays constant or decreases accordingly as relative risk aversion is an increasing, constant or decreasing function of income'.

Slemrod (1985) reports a negative relation of income and tax compliance in his analysis of US treasury tax file for 1977.A positive relation of income and tax compliance also found empirical support (Alm et al., 1992). Higher (true) income leads to higher reported income, with estimated reported-income elasticity between 0 and 1 (Alm et al, (1992).Other studies found no relation of income level and tax compliance. Feinstein (1998) compared pooled data from the 1982 and 1985 TCMP and found no significant effects of income on tax compliance. Andreoni et al., (1998) indicates that as income rises, tax evasions should increase over most ranges.

Chau and Leung (2009) also reveal the respondents in the lower income group tend to have a lower proportion of tax compliance by under-reporting income and by over-claiming expenses than their counterparts in the higher income group. Definite conclusions cannot be drawn from the empirical studies reported and hence the study hypothesizes that the level of actual income does not influence tax compliance.

$H_{O 2}$ : Tax audits have no significant effect on tax compliance.

\subsection{Fines and Penalties}

Fines and Audit rates may substitute each other due to their multiplicative linkages as long as neither of them is set to zero (Kirchler et al 2007).Higher fines simply make evading taxes more hazardous for taxpayers and should deter from evasion. Empirically the deterrent effect of fines could not always be supported. The observed effects were weaker than expected and some studies even suggest that an increase of penalties can have undesirable effect and result in more tax avoidance (Kirchler et al, (2007).

Fines and Audit rates may substitute each other due to their multiplicative linkages as long as neither of them is set to zero (Kirchler et al 2007).Higher fines simply make evading taxes more hazardous for taxpayers and should deter from evasion. Alm et al., (1992) supports the evidence that fines do affect tax compliance though the impact was virtually zero. Friedland et al, (1978) compliance was stronger affected by the amount of fines than by audit probabilities. Several studies however found no support for the deterring effects of fines since it was weak (Andreoni 1998).Some of the findings suggest that a policy based on deterrence is effective only in combination with frequent Audits (Kirchler et al., 2007).

The most extreme penalties will have no effect, if it is common knowledge that audits virtually do not occur. The increasing tax avoidance and tax resistance due to an increase of fines puts into question how fines should be assessed to be effective. On the one hand fines should be high enough to decrease the expected value of tax evasion and to assure its deterrent effect on tax payers. On the other hand, if fines are too high, the tax system would be perceived as unjust and unfair and taxpayers would use any possibility to legally avoid taxes (Kirchler et al., 2007).In Kenya for instance, the maximum penalty for tax evasion is $200 \%$ of the evaded amount (Sec 72 D IT Act cap 470).In summary evidence suggests fines have mixed impact on tax compliance, the study hypothesize that fines have no significant impact on tax compliance.

$H_{O 3}$ : Fines and penalties do not significantly influence tax compliance.

\section{Research Methodology}

This study used survey design to analyze the effect of economic factors on tax compliance. The target population for the study was 1470 financial managers of limited liability companies issued with a trade license from Eldoret Municipal council (Municipal Database, 2012). The study utilized a sample of 320 companies. The study obtained a sample size range of 240 respondents. Stratified random sampling was used to categorize companies according to sectors (Stratus) after which the study employed systematic random sampling technique to select firms sampled in each strata in order to get a representative sample size. Primary data was collected using a well-structured questionnaire with a 5 Likert scale.

\subsection{Data Analysis}

This section deals with organizing, analyzing, interpreting and presenting the collected data. It entails the separation of data into constitute parts for examination. In data analysis the study draws conclusion concerning the relationship and difference, which were found in the research results. Since the data collected was quantitative, the data was summarized using descriptive statistics. Descriptive statistics enables the researcher to meaningfully describe a distribution of scores or measurements using a few 
indices or statistics. Multiple regressions as well as the Pearson Correlation were undertaken in the analysis of data.

\subsection{Model Specification}

The model used in the analysis provides the extent to which the independent variables affect dependent variable, further, data was tested for normality, multicollinearity and linearity test.

The multiple regression model used in this study is given as;

$\mathrm{Y}=\alpha+\beta_{1} \mathrm{X}_{1}+\beta_{2} \mathrm{X}_{2}+\beta_{3} \mathrm{X}_{3}+\beta_{4} \mathrm{X}_{4}+\beta_{5} \mathrm{X}_{5+} \varepsilon$

Where,

$$
\begin{aligned}
& \mathrm{Y}=\text { Tax Compliance } \\
& \alpha=\text { Constants } \\
& \beta_{1} \ldots \beta_{5}=\text { the slope which } \\
& \text { degree with which tax compl } \\
& \text { the independent variable chang } \\
& \text { variables. } \\
& \mathrm{X}_{1}=\text { Tax Rates } \\
& \mathrm{X}_{2}=\text { Tax Audits } \\
& \mathrm{X}_{3}=\text { Level of Actual Income } \\
& \mathrm{X}_{4}=\text { Fines and Penalties } \\
& \mathrm{X}_{5} \text { Tax Incentives } \\
& \varepsilon=\text { error term }
\end{aligned}
$$$$
\beta_{1} \ldots \beta_{5}=\text { the slope which represents the }
$$
degree with which tax compliance changes as the independent variable change by one unit
From the findings majority of the respondents, 130 (58.3\%) were male aged between 20 and 30 years of age. The findings indicated that the highest level of education for majority of the respondents, $70(31.4 \%)$, was professional while $68(30.5 \%)$ had a certificate/ diploma. Another $55(24.7 \%)$ had attained a degree. the main business activity that the respondents were involved in was retail/ wholesale, $62(27.8 \%)$. And majority of the respondents, $84(37.7 \%)$, had been in the business for 6 to 10 years with annual turn-over of 5 to 10 million.

\subsection{Descriptive Statistics and Correlation Results}

The results in table 1 revealed that level of compliance was low together with financials and penalties imposed against non compliance of tax. Nevertheless, tax audit was relatively high. Further, from the findings, there is a clear indication of a positive and significant relationship between the various independent factors and tax compliance as a dependent factor at 0.01level of significance. The table shows that tax rates have a positive and significant relationship with tax compliance with a correlation value of 0.607 , tax audits had 0.632 which represented the most significant relationship, level of actual income had the lowest with a correlation value of 0.420 , fines and penalties had a

\begin{tabular}{|c|c|c|c|c|c|c|c|c|c|}
\hline & Mean & $\begin{array}{c}\text { Standard } \\
\text { Deviation }\end{array}$ & Skewness & Kurtosis & $\begin{array}{c}\text { Tax } \\
\text { compliance }\end{array}$ & $\begin{array}{c}\text { Tax } \\
\text { rates }\end{array}$ & $\begin{array}{c}\text { Tax } \\
\text { audit }\end{array}$ & $\begin{array}{c}\text { Fines } \\
\text { and } \\
\text { penalties }\end{array}$ & \\
\hline $\begin{array}{l}\text { Tax } \\
\text { compliance }\end{array}$ & 3.2973 & 0.66137 & 0.075 & 0.446 & 1 & & & & \\
\hline Tax rates & 3.3913 & 0.89146 & -0.223 & -0.4 & $0.607 * *$ & 1 & & & \\
\hline Tax audit & 3.9114 & 0.79607 & -0.84 & 0.015 & $0.632 * *$ & $0.412 * *$ & 1 & & \\
\hline $\begin{array}{l}\text { Fines and } \\
\text { penalties }\end{array}$ & 3.5703 & 0.76721 & -0.453 & -0.443 & $0.601 * *$ & $0.436^{* *}$ & $0.470 * *$ & $0.453 * *$ & 1 \\
\hline
\end{tabular}
correlation value of 0.601 while tax incentives had a correlation value of 0.520 . Inter- independent factor correlation was also shown to be significant with the highest being between tax audits and fines and penalties which confirms the observation that the policy based on deterrence is effective only in combination with frequent Audits (Kirchler et al., 2007).

\section{Study results}

Table 1: Correlation Analysis

** Correlation is significant at the 0.01 level (2-tailed)

Source: (Survey Data, 2012)

\subsection{Testing Hypothesis}

The regression results in table 4.13 show that each of the predicted parameters in relation to the independent factors were significant; $\beta_{1}=0.317$ ( $p$-value $=0.000$ which is less than $\alpha=$ 0.05 ) which implies that we reject the null hypothesis stating that there is no significant relationship between tax rates and tax compliance. The findings agree with those of Kirchler et al. (2007) who points out that tax rate is an important factor in determining tax compliance behavior although the exact impact is still unclear and debatable; an assertion which was confirmed by Clotfelter (1983) who claimed that 'reducing tax rates is not the only policy that has the potential to discourage tax evasion'. This is because tax rates have mixed impact on tax compliance and as such, tax rates appeared to be insignificant in determining tax evasion.
The table also shows that $\beta_{2}=0.331$ ( $\mathrm{p}$-value $=0.000$ which is less than $\alpha=0.05$ ) which indicates that we reject the null hypothesis and infer that that there is significant relationship between tax audits and tax compliance. These findings agree with those of Hyun (2005) who posits that tax audit is one of the most effective policies to protect the behavior of tax evasion. Also Friedland et al., (1978) found out that a higher (random) audit rate leads to more compliance. Although this is the case, Alm et al. (1992) find that this impact appears to be small and nonlinear.

The findings also showed that $\beta_{4}$ was 0.194 (p-value $=0.000$ which is less than $\alpha=0.05$ ) which implies that we reject the null hypothesis and conclude that there is o significant relationship between fines and penalties and tax compliance. relation to past findings, although there was an indication at some point in some findings, empirically, that the deterrent effect of fines could not 
always be supported, higher fines simply make evading taxes more hazardous for taxpayers and should deter from evasion. The results also affirm those of Alm et al. (1992) who support the evidence that fines do affect tax compliance though the impact was virtually zero and Friedland et al. (1978) who found out that compliance was stronger affected by the amount of fines than by audit probabilities.
The rule of thumb was applied in the interpretation of the variance inflation factor. From table 4.13, the VIF for all the estimated parameters was found to be less than 5 which indicate the absence of multi-collinearity among the independent factors. This implies that the variation contributed by each of the independent factors was significant independently and all the factors should be included in the prediction model.

Table 2 Test of hypothesis

\begin{tabular}{|c|c|c|c|c|c|c|c|}
\hline & \multicolumn{2}{|c|}{$\begin{array}{l}\text { Unstandardized } \\
\text { Coefficients }\end{array}$} & \multicolumn{3}{|c|}{ Standardized Coefficients } & \multicolumn{2}{|c|}{ Collinearity Statistics } \\
\hline & B & Std. Error & Beta & $\mathbf{t}$ & Sig. & Tolerance & VIF \\
\hline (Constant) & -0.391 & 0.274 & & -1.428 & 0.155 & & \\
\hline Tax rates & 0.302 & 0.046 & 0.317 & 6.531 & 0.000 & 0.725 & 1.379 \\
\hline Tax Audit & 0.386 & 0.059 & 0.331 & 6.557 & 0.000 & 0.669 & 1.495 \\
\hline Fines and Penalties & 0.208 & 0.057 & 0.194 & 3.646 & 0.000 & 0.6 & 1.666 \\
\hline \multicolumn{8}{|l|}{ Model summary } \\
\hline R Square & 0.647 & & & & & & \\
\hline Adjusted R Square & 0.638 & & & & & & \\
\hline Durbin-Watson & 1.929 & & & & & & \\
\hline $\mathrm{F}$ & 75.739 & & & & & & \\
\hline Sig. & 0.000 & & & & & & \\
\hline
\end{tabular}

Dependent Variable: Tax Compliance

\section{Conclusion and recommendation}

From the study findings, it was shown that the various factors that affect tax compliance were significant. It should thus be pointed out that tax compliance is a major problem for many tax authorities and it is not an easy task to persuade taxpayers to comply with tax requirements even though 'tax laws are not always precise' (James and Alley 2004). The difficulty attributed to tax compliance is steeped in various factors considered independently and also jointly.

The study concluded that improving tax rates such as making the level of the current VAT tax rate and current Corporate Income Tax fair will improve the level of tax compliance. Moreover well communication of Tax Rates and making tax rates ease to apply in computation for ease tax obligations to the public will positively enhance tax compliance level.

Based on the study findings tax audit positively influence the level of tax compliance. Thus, efficient communication of Audit Standards and Procedures by the Tax Auditors, availing Audit Findings to the public on time and Tax Auditors being friendly and informative to them will increase level of tax compliance. Finally, the study concludes that fine and penalties affect level of tax compliance, further, introduction of more and better tax incentives improve level of actual level of income.

It should be noted that taxpayers vary in terms of the opportunities available to them to overstating expenses and understating incomes (Chau and Leung 2009). Greater tax noncompliance opportunity is generally resulted from selfemployment and income sources not subject to withholding taxes. Thus, in the quest to ensure higher compliance, the concerned authorities should ensure that incentives are greater for both local and international investors and that the rates are attractive. Although past studies have shown that the effect of fines and penalties are negative in relation to tax compliance, the study showed that the effect was significant and was in agreement with other studies which pointed out the significance of fines and penalties on compliance. Thus, fines and penalties should be enforced effectively so that they can act as a deterrent to non-compliance by companies.

This study identified the economic factors affecting tax compliance of limited liability companies within Eldoret Municipality.

From the study findings, the findings were only limited to the economic factors in relation to the companies. Thus, more research and studies should be carried out to determine noneconomic factors that affect tax compliance. Some of the factors can be those in attitudes toward taxes, personal, social and national norms and finally the perceived fairness of the tax system. This would enable the researchers and concerned companies to mitigate negative effects of such non-economic factors and hence enhance their tax compliance.

\section{References and notes}

1. Ajzen, I. (1991). Theory of planned behavior. Organizational Behavior and Human Decision Processes, 50, 179-211, CrossRef

2. Allingham, M.G., and Sandmo, A. (1972). Income tax evasion: A theoretical analysis. Journal of Public Economics, 1(3-4), 323-38, CrossRef

3. Andreoni, J., B. Erard, and J. Feinstein (1998).Tax Compliance. Journal of Economic Literature, 36, 818-60.

4. Benno Torgler and Friedrich Schneider (2005): Attitudes towards Paying Taxes in Austria: An Empirical Analysis, 32(2), 231-246. 
5. Clotfelter, C. (1983). Tax Evasion and Tax Rates: An Analysis of Individual Returns. Review Economics and Statistics, LXV (3), 36373, CrossRef

6. Chow, C.Y. (2004). Gearing up for the self-assessment tax regime for individuals. Tax National, 2nd quarter, 20-23.

7. Erich Kirchler, Stephan Muehlbacher, Barbara Kastlunger and Ingrid Wahl (2007);

1. Why Pay Taxes? A Review of Tax Compliance Decisions, International Studies Program Working Paper 07-30.

8. Feinstein, J. (1991). An Econometric Analysis of Income Tax Evasion and Its Detection. Rand Journal of Economics, Vol. 22, No. 1, pp. 14-35, CrossRef

9. Gerald Chau and Patrick Leung 2009.A critical review of Fischer tax compliance model: A research synthesis. Journal of Accounting and Taxation Vol.1 (2), pp. 034-040

10. Ho Juan Keng, Loo Ern Chen and Lim Kwee Pheng (2006); Perspective of non-taxpayers' perceptions on issues of ethics and equity in tax compliance. Malaysian Accounting Review Vol.5 No.2

11. Income Tax Act Cap 470 Laws of Kenya,

12. James Alm (1991) A Perspective on the Experimental Analysis of Taxpayer Reporting; The Accounting Review, The Accounting Review, Vol. 66, No. 3 (Jul., 1991), pp. 577-593

13. James Alm, Betty R. Jackson and Michael McKee (1992);

2. Estimating the determinants of taxpayer compliance with experimental data, National Tax Journal, Vol. 45, no. 1, (March, 1992), pp. 107-14.

14. James S. and Alley C. (1999) Tax compliance, Self-Assessment and Tax Administration in New Zealand. New Zealand Journal of Taxation Law and Policy, Vol 5, No 1 pp. 3-14.

15. Jin Kwon Hyun (2005); Tax Compliance in Korea and Japan: Why are they different?

16. Joel Slemrod (1985); An Empirical Test for Tax Evasion: The Review of Economics and Statistics, Vol. 67, No. 2, pp. 232-238, CrossRef

17. John Hasseldine and Zhuhong LI (1999); More tax evasion research required in new millennium. Crime, Law and Social Change, 31 (1), 91-104, CrossRef

18. Kenya Government Economic Survey 2002

19. KRA Domestic Taxes department; Income Tax at a glance 2011

20. KRA Domestic Taxes department; VAT at a glance 2011

21. Mansor, M., Tayib, M., and Yusof, R.N. (2005). Tax administration system: a study on the efficiency of Malaysian indirect taxes. International Journal of Accounting, Auditing and Performance Evaluation, 2(3), 321-43, CrossRef

22. Martin M Masinde and Phyllis Makau (2010); Unlocking the Revenue Potential in Kenya. Parliamentary Service Commission, Parliamentary Budget Office

23. Mohd Rizal Palil and Ahmad Fariq Mustapha (2011); Determinants of Tax Compliance in Asia: A case of Malaysia, European Journal of Social Sciences Vol 24 No 1.

24. Nehemiah Friedland, Shlomo Maital and Aryeh Rotenberg (1978); A simulation study of income tax evasion, 8, 107-116.

25. Nicoleta Barbuta-Misu (2011) A Review of Factors for Tax Compliance,

26. Song, Y.D. and T.E. Yarbrough, 1978. Tax ethics and taxpayer attitudes: A survey. Public Administration Review, 38(5), 442-452, CrossRef

27. Serkan Benk, Ahmet Ferda Cakmak and Tamer Budak (2011); An Investigation of Tax compliance Intention: A Theory of Planned Behavior Approach, European Journal of Economics, Finance and Administration Sciences Issue 28.

28. Tax Matters PWC 2008.

29. Timothy R. Hinkin; A Review of Scale Development Practices in the Study of Organizations: Journal of Management 1995, Vol. 21, No. 5.967-988

30. VAT Act Cap 476 Laws of Kenya 